\title{
G250 Peptide Vaccine
}

National Cancer Institute

\section{Source}

National Cancer Institute. G250 Peptide Vaccine. NCI Thesaurus. Code C53410.

A cancer vaccine containing of a synthetic form of the renal cell carcinoma (RCC)associated antigen G250 with potential antineoplastic activity. Vaccination with G250 peptide vaccine may stimulate the host immune system to mount a cytotoxic $T$ lymphocyte (CTL) response ag ainst tumor cells positive for the G250 antigen, resulting in decreased tumor growth. Found in the majority of renal cell carcinomas, G250 is a cell surface tumor-associated antigen (TAA) that contains an HLA-A2.1-restricted epitope that is recognized by CT LS. 